\title{
ОРГАНИЗАЦИОННО-ЭКОНОМИЧЕСКИЕ ИССЛЕДОВАНИЯ МЕДИЦИНСКОЙ И ФАРМАЦЕВТИЧЕСКОЙ ПОМОЩИ БОЛЬНЫМ ПСОРИАЗОМ
}

\author{
(С Солянина В.А. ${ }^{1}$ Овод А.И. ${ }^{2}$, Комиссинская И.Г. ${ }^{3}$, Силина Л.В. \\ ${ }^{1}$ Кафедра общественного здоровья и здравоохранения, ${ }^{2}$ кафедра управления и экономики фармации, \\ ${ }^{3}$ кафедра фармации ФПО, ${ }^{4}$ кафедра дерматовенерологии \\ Курского государственного медицинского университета, Курск \\ E-mail: soljan@yandex.ru
}

\begin{abstract}
Настоящая статья посвящена научному обоснованию организационно-экономических подходов к совершенствованию медицинской и фармацевтической помощи больным псориазом на основании формирования оптимального лекарственного бюджета специализированной медицинской организации. Исходя из систематизации данных федеральных клинических рекомендаций и медицинских карт стационарных больных с диагнозом псориаз, пролеченных в круглосуточном стационаре Курского областного клинического кожно-венерологического диспансера, проведен анализ ассортимента лекарственных средств фактической терапии псориаза, определена структура назначаемого ассортимента в зависимости от интенсивности потребления по группам АТС-классификации. По результатам интегрированного ABC/XYZ-анализа потребления лекарств были выделены приоритетные лекарственные препараты для закупок, квалифицированные в четыре условные статусные группы, дана стоимостная оценка лекарственного бюджета в целом и в разрезе каждой статусной группы.
\end{abstract}

Ключевые слова: псориаз, организация медицинской помощи, фармацевтическая помощь, лекарственный бюджет, АВС-анализ, XYZ-анализ.

\section{ORGANIZATIONAL AND ECONOMIC RESEARCH OF MEDICAL AND PHARMACEUTICAL CARE FOR PATIENTS WITH PSORIASIS}

Solyanina V.A. ${ }^{l}$, Ovod A.I. ${ }^{2}$, Komissinskaia I.G. ${ }^{3}$, Silina L.V. ${ }^{4}$

${ }^{1}$ Department of Public Health and Health Service, ${ }^{2}$ Department of Management and Economics of Pharmacy, ${ }^{3}$ Department of Pharmacy of Post-graduate Education Faculty, ${ }^{4}$ Department of Dermatovenereology of Kursk State Medical University, Kursk

The article is devoted to the scientific justification of organizational and economic approaches to improving medical and pharmaceutical care for patients with psoriasis on the basis of setting the optimal medicinal budget of a specialized healthcare organization. The research was based on the systematization of federal clinical recommendations data and the medical records of in-patients with a diagnosis of psoriasis treated at the twenty-four-hour in-patient hospital of the Kursk Regional Clinical Dermatovenerologic Dispensary. Collected data was used for the analysis of the medicines assortment for the actual therapy of psoriasis and for the identification of the structure of the prescribed assortment depending on the intensity of consumption among the groups under ATS-classification. As a result of the integrated $\mathrm{ABC} / \mathrm{XYZ}$ analysis of drug consumption, priority medicines for procurement were identified and classified in four conditional status groups. Moreover, the cost estimation of the medicinal budget was made in context of general framework and for each status group separately.

Keywords: psoriasis, organization of medical care, pharmaceutical care, medicinal budget, ABC-analysis, XYZ-analysis.

Значительную долю в структуре кожных заболеваний как среди взрослого, так и среди детского населения занимает псориаз. Фармакоэпидемиологические исследования свидетельствуют о широкой распространенности заболевания примерно 5\% населения Земли, по другим данным $1-2 \%$ жителей развитых стран страдают псориазом [8].

Псориаз - это воспалительное иммуноассоциированное заболевание мультифакторной природы с доминирующей ролью генетических факторов [5]. Его тяжесть и частота рецидивов связаны с эндокринными и метаболическими нарушениями: общий дефицит мелатонина, повышенный уровень гормона роста и инсулиноподобного фактора роста-1 в крови, снижение функции щитовидной железы, недостаточность коры надпо- чечников [2].

Псориаз обусловливает снижение качества жизни, работоспособности и социальной активности больных. Являясь медико-социальной проблемой, он требует значительных затрат системы здравоохранения и прямых платежей пациентов на медицинскую помощь и лекарственную терапию [3].

Цель настоящего исследования заключается в научном обосновании организационноэкономических подходов к совершенствованию медицинской и фармацевтической помощи больным псориазом на основании формирования оптимального лекарственного бюджета специализированной медицинской организации.

Предмет исследования - медицинская и фармацевтическая помощь больным псориазом. 


\section{МАТЕРИАЛЫ И МЕТОДЫ ИССЛЕДОВАНИЯ}

Для анализа использовались показатели распространенности и заболеваемости псориазом в стране и в Курской области за период 20062015 гг. [11]; медицинские карты стационарных больных с диагнозом псориаз, пролеченных в круглосуточном стационаре Курского областного клинического кожно-венерологического диспансера (КОККВД) в 2015-2016 гг. (191); федеральные клинические рекомендации, схемы фармакотерапии, используемые в лечении больных с псориазом $[9,10]$; данные государственного реестра лекарственных средств (ЛС) (интернет-версия 2016 г.); справочник синонимов ЛС (2016 год).

Методы исследования: ситуационный, логический, маркетинговый, фармацевтический анализ, статистические методы (табличный, графический, вариационная статистика), клиникоэкономический анализ (АВС, XYZ).

\section{РЕЗУЛЬТАТЫ ИССЛЕДОВАНИЯ И ИХ ОБСУЖДЕНИЕ}

Общее число больных псориазом в Курской области в 2015 году составило 2269 человек или 203,1 на 100 тысяч населения, что составляет $87,0 \%$ от общероссийского уровня $(233,4$ на 100 тысяч населения), но выше показателя по Центральному федеральному округу (194,0 на 100 тысяч населения) на 4,7\%. При этом впервые в Курской области в 2015 году было зарегистрировано 487 случаев псориаза или 43,6 на 100 тысяч населения, из них 31 у детей 0-17 лет (15,5 на 100 тысяч соответствующего населения) [11].

Особенность течения псориаза заключается в том, что наиболее тяжелые формы заболевания требуют стационарного лечения. Установлено, что в структуре госпитализаций в специализированной медицинской организации КОККВД более
$40 \%$ приходится на больных с диагнозом псориаз, второе место занимает экзема $(12,1 \%)$, на третьем месте атипический псориаз $(9,6 \%)$. Таким образом, половина всех больных, пролеченных в дерматологических отделениях КОККВД, - это пациенты с диагнозом псориаз, причем 63,8\% из них госпитализировались в круглосуточный стационар и $36,2 \%$ - в дневной. Использование стационарзамещающих технологий позволяет снижать затраты на питание, заработную плату персонала, коммунальные услуги, но лекарственное обеспечение предоставляется пациентам в полном объеме. Начиная с 2009 года происходило постепенное снижение длительности лечения больных псориазом с 20,9 до 17,5 дней.

В связи со спецификой течения определены показатели сезонности госпитализации больных псориазом. Максимальный уровень наблюдается в начале года: февраль $(168,2 \%)$, март $(144,6 \%)$, апрель $(134,3 \%)$. Затем происходит спад числа госпитализаций с постепенным возрастанием их количества к концу года. В дневном стационаре высокий уровень госпитализации сохраняется до июня включительно. Результаты анализа сезонности важны при планировании кадрового, материального, лекарственного обеспечения специализированных отделений, оказывающих помощь больным псориазом.

Важным компонентом планирования объемов медицинской помощи являются медикосоциальные характеристики пациентов. Установлено, что больные псориазом в Курской области это преимущественно мужчины $(56,0 \%)$, старше 60 лет $(35,1 \%)$, проживающие в городе $(65,4 \%)$, по профессии рабочие $(31,0 \%)$, на момент госпитализации безработные $(24,1 \%)$, что может быть обусловлено состоянием их здоровья; в среднем имеют одно сопутствующее заболевание (артериальную гипертензию $(41,5 \%)$, хронический гастродуоденит $(21,3 \%)$ или хроническую сердечную недостаточность $(20,2 \%))$.

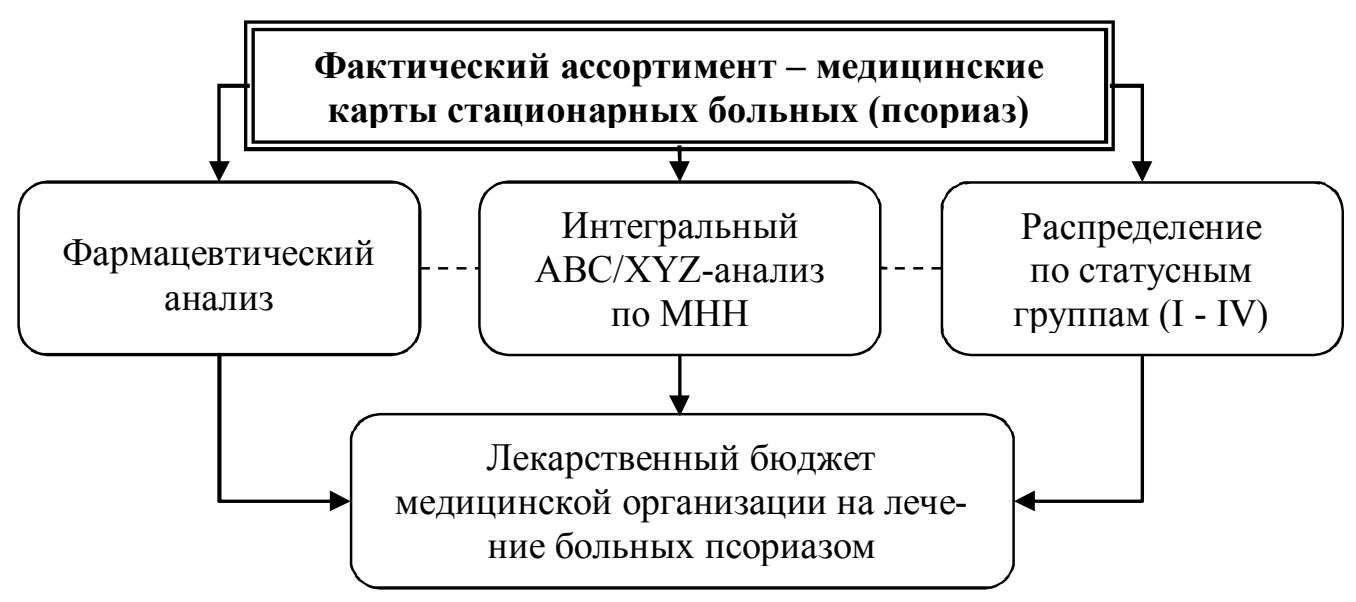

Рис. 1. Алгоритм формирования лекарственного бюджета специализированной медицинской организации на оказание медицинской и фармацевтической помощи больным псориазом. 
Одной из основных технологий лечения псориаза является консервативная фармакотерапия с применением значительного ассортимента лекарственных препаратов в зависимости от вида, тяжести и степени распространенности заболевания. Так как выбор тактики лечения пациента в условиях стационара требует наличия определенного ассортиментного портфеля, специализированной медицинской организации, важно определить лекарственный бюджет на оказание медицинской и фармацевтической помощи больным псориазом (рис. 1).

На первом этапе был сформирован массив назначаемых препаратов, который включал ассортимент из 79 международных непатентованных наименований (МНH) в виде 115 лекарственных препаратов (ЛП), систематизированных в 11 групп АТС-классификации, что дало возможность проанализировать структуру фактической терапии (таблица 1).

Значительную долю в структуре назначений составляет специфическая терапия, представленная группой D - препараты, применяемые в дерматологии - 26,1\% (30 ЛП и $18 \mathrm{MHН),} \mathrm{в} \mathrm{которой}$ превалирует подгруппа D07 - кортикостероиды, применяемые в дерматологии (17 ЛП (14,8\%)), включающие следующие МНН: алклометазон, бетаметазон, гидрокортизон, клобетазон, метилпреднизолона ацетат, мометазон, флуоцинола ацетонид, бетаметазон + салициловая кислота, гидрокортизон + окситетрациклин, гидрокортизон в комбинации с антисептиком, флуметазон + салициловая кислота.

Второе место в фармакотерапии занимает группа С - сердечно-сосудистая система 19,1\% (22 ЛП и $16 \mathrm{MHН),} \mathrm{применяемая,} \mathrm{в} \mathrm{том} \mathrm{числе,} \mathrm{для}$ лечения сопутствующих заболеваний, что подтверждается медико-социальными характеристиками пациентов.

Третье место принадлежит группе A - пищеварительный тракт и обмен веществ - 14,8\% (17 ЛП и 12 МНН), включающая подгруппы: A10 - препараты для лечения сахарного диабета, A11 - витамины, А12 - минеральные добавки (по 3,5\%), а также четыре подгруппы, связанные с заболеваниями желудочно-кишечного тракта (ЖКТ): А02 - препараты для лечения заболеваний, связанных с нарушением кислотности (омез таблетки); А03 - препараты для лечения функциональных нарушений ЖКТ (но-шпа таблетки); A05 - препараты для лечения заболеваний печени и желчевыводящих путей (эссенциале капсулы и раствор для внутривенного введения, карсил драже); А16 - другие препараты для лечения заболеваний ЖКТ и нарушений обмена веществ (гептор таблетки, липоевая кислота таблетки).
Четвертая позиция, группа $\mathrm{R}$ - дыхательная система, представлена в основном подгруппой R06 - антигистаминные средства системного действия - 8,7\% (10 ЛП), которые широко применяются как при псориазе, так и при других кожных патологиях.

В фактическом ассортименте также представлены группа J - противомикробные препараты системного действия (доксициклин капсулы, кларбакт таблетки, цефтриаксон порошок для внутримышечного введения, юнидокс солютаб таблетки, нимесил гранулы и др.), группа М костно-мышечная система (диклофенак раствор внутримышечный, индометацин таблетки, мовалис таблетки, найз таблетки, диклофенак гель, вольтарен гель, индометацин мазь), группа В кровь и система кроветворения (цианокобаламин раствор для инъекций, фолиевая кислота таблетки, гемодез раствор для инфузий и др.).

Результаты анализа фактической терапии в разрезе интенсивности потребления по группам АТС-классификации (графы 6, 7 таблица 1) позволили установить, что 29,6\% всех назначений это препараты группы D, в которой, в свою очередь, превалирует подгруппа D07 - кортикостероиды $(20,9 \%)$, что соответствует и их значительной доле в структуре назначаемого ассортимента $(14,8 \%)$ и включению препаратов данной подгруппы в регламентирующие документы по схемам лечения псориаза.

Достаточная высокая интенсивность назначений характерна и для препаратов подгруппы A11 - витамины (13,6\%), В03 - анемические препараты (12,1\%), В05 - кровезаменители и перфузионные растворы (7,7\%), V03 - другие лечебные средства (тиопентал натрия раствор для инъекций, 8,8\%).

В общей сложности 191 пациенту было выполнено 2324 назначения ЛП, что в среднем составляет 12 ЛП на одного больного. Анализ назначений свидетельствует о том, что пациентам ЛП назначались часто однократно (36 ЛП применялись однократно), осуществлялся подбор индивидуальной фармакотерапии в зависимости от факторов, влияющих на течение болезни (препарат применялся от одного до трех дней и заменялся на другой). Эти данные еще раз подтверждают сложность выполнения стандартов, клинических рекомендаций для всех категорий больных даже с одинаковой патологией, необходимость индивидуального подхода к каждому пациенту, что также влияет на экономическую составляющую процесса фармацевтической помощи, но вместе с тем позволяет повысить качество жизни больных с кожными патологиями за более короткий срок. 
Таблица 1

Структура фактических назначений лекарственных средств при лечении псориаза по группам АТС-классификации

\section{Наименование групп АТС-классификации}

\begin{tabular}{|c|c|c|c|c|c|}
\hline \multicolumn{2}{|c|}{ МНH } & \multicolumn{2}{|c|}{ ЛП } & \multicolumn{2}{|c|}{$\begin{array}{l}\text { Количество } \\
\text { назначений }\end{array}$} \\
\hline абс. & доля, \% & абс. & доля, \% & аббc. & доля, \% \\
\hline 2 & 3 & 4 & 5 & 6 & 7 \\
\hline 12 & 15,19 & 17 & 14,78 & 552 & 23,75 \\
\hline 1 & 1,27 & 1 & 0,87 & 8 & 0,34 \\
\hline 1 & 1,27 & 1 & 0,87 & 1 & 0,04 \\
\hline 2 & 2,53 & 3 & 2,61 & 114 & 4,91 \\
\hline 2 & 2,53 & 4 & 3,48 & 6 & 0,26 \\
\hline 2 & 2,53 & 4 & 3,48 & 315 & 13,55 \\
\hline 2 & 2,53 & 2 & 1,74 & 14 & 0,60 \\
\hline 2 & 2,53 & 2 & 1,74 & 94 & 4,04 \\
\hline 3 & 3,80 & 5 & 4,35 & 474 & 20,40 \\
\hline 1 & 1,27 & 2 & 1,74 & 13 & 0,56 \\
\hline 2 & 2,53 & 2 & 1,74 & 282 & 12,13 \\
\hline- & - & 1 & 0,87 & 179 & 7,70 \\
\hline 16 & 20,25 & 22 & 19,13 & 59 & 2,54 \\
\hline 4 & 5,06 & 4 & 3,48 & 5 & 0,22 \\
\hline 4 & 5,06 & 5 & 4,35 & 14 & 0,60 \\
\hline 1 & 1,27 & 1 & 0,87 & 1 & 0,04 \\
\hline- & - & 1 & 0,87 & 1 & 0,04 \\
\hline 3 & 3,80 & 5 & 4,35 & 12 & 0,52 \\
\hline 3 & 3,80 & 5 & 4,35 & 24 & 1,03 \\
\hline 1 & 1,27 & 1 & 0,87 & 2 & 0,09 \\
\hline 18 & 22,78 & 30 & 26,09 & 687 & 29,56 \\
\hline 3 & 3,80 & 3 & 2,61 & 8 & 0,34 \\
\hline 2 & 2,53 & 3 & 2,61 & 96 & 4,13 \\
\hline 1 & 1,27 & 2 & 1,74 & 88 & 3,79 \\
\hline 7 & 8,86 & 17 & 14,78 & 486 & 20,91 \\
\hline 2 & 2,53 & 2 & 1,74 & 4 & 0,17 \\
\hline 2 & 2,53 & 2 & 1,74 & 4 & 0,17 \\
\hline 1 & 1,27 & 1 & 0,87 & 1 & 0,04 \\
\hline 2 & 2,53 & 2 & 1,74 & 2 & 0,09 \\
\hline 2 & 2,53 & 2 & 1,74 & 2 & 0,09 \\
\hline 7 & 8,86 & 8 & 6,96 & 19 & 0,82 \\
\hline 3 & 3,80 & 4 & 3,48 & 10 & 0,43 \\
\hline 2 & 2,53 & 2 & 1,74 & 3 & 0,13 \\
\hline 2 & 2,53 & 2 & 1,74 & 6 & 0,26 \\
\hline 1 & 1,27 & 2 & 1,74 & 99 & 4,26 \\
\hline 1 & 1,27 & 1 & 0,87 & 1 & 0,04 \\
\hline- & - & 1 & 0,87 & 98 & 4,22 \\
\hline 4 & 5,06 & 8 & 6,96 & 74 & 3,18 \\
\hline 4 & 5,06 & 5 & 4,35 & 42 & 1,81 \\
\hline 2 & 2,53 & 3 & 2,61 & 32 & 1,38 \\
\hline
\end{tabular}

А - пищеварительный тракт и обмен веществ А02 - препараты для лечения заболеваний, связанных с нарушением кислотности

А03 - препараты для лечения функциональных нарушений ЖКТ

А05 - для лечения заболеваний печени и желчевыводящих путей

А10 - препараты для лечения сахарного диабета

А11 - витамины

А12 - минеральные добавки

А16 - другие препараты для лечения заболеваний

ЖКТ и нарушений обмена веществ

В - кровь и система кроветворения

В01 - антитромботические средства

В03 - антианемические препараты

В05 - кровезаменители и перфузионные растворы

С - сердечно-сосудистая система

С01 - препараты для лечения заболеваний сердца

С03 - диуретики

С04 - периферические вазодилататоры

С05 - ангиопротекторы

С07 - бета-адреноблокаторы

С09 - средства, действующие на ренинангиотензиновую систему

С10 - гиполипидемические средства

D - препараты, применяемые в дерматологии

D01 - противогрибковые препараты

D02 - препараты со смягчающим и защитным действием

D03 - препараты для лечения ран и язв

D07 - кортикостероиды

D08 - антисептики и дезинфицирующие препараты

D10 -препараты для лечения угревой сыпи

D11- прочие препараты для лечения заболеваний кожи

Н - гормональные препараты системного действия

Н02 - кортикостероиды системного действия

J - противомикробные препараты системного действия

J01 - антибактериальные препараты системного действия

J02 - противогрибковые препараты системного дей-

ствия

J05 - противовирусные препараты системного действия

L - противоопухолевые препараты и иммуномодуляторы

L01 - противоопухолевые препараты

L03 - иммуностимуляторы

М - костно-мышечная система

М01 - противовоспалительные и противоревматиче-

ские препараты

М02 - нестероидные противовоспалительные средства

2,53 
Таблица 1 (продолжение)

Структура фактических назначений лекарственных средств при лечении псориаза по группам АТС-классификации

\begin{tabular}{|c|c|c|c|c|c|c|}
\hline \multirow[t]{2}{*}{ Наименование групп АТС-классификации } & \multicolumn{2}{|c|}{ МHН } & \multicolumn{2}{|c|}{ ЛП } & \multicolumn{2}{|c|}{$\begin{array}{l}\text { Количество } \\
\text { назначений }\end{array}$} \\
\hline & абос. & доля, \% & абоc. & доля, \% & аб̆c. & доля, \% \\
\hline 1 & 2 & 3 & 4 & 5 & 6 & 7 \\
\hline N- нервная система & 3 & $\mathbf{3 , 8 0}$ & 3 & 2,61 & 72 & 3,10 \\
\hline N05 - психотропные средства & 1 & 1,27 & 1 & 0,87 & 16 & 0,69 \\
\hline N06 - психоаналептики & 1 & 1,27 & 1 & 0,87 & 50 & 2,15 \\
\hline $\begin{array}{l}\text { N07 - другие препараты для лечения заболеваний } \\
\text { нервной системы }\end{array}$ & 1 & 1,27 & 1 & 0,87 & 6 & 0,26 \\
\hline $\mathbf{R}$ - дыхательная система & 11 & 13,92 & 15 & 13,04 & 81 & 3,49 \\
\hline R01 - назальные препараты & - & - & 1 & 0,87 & 1 & 0,04 \\
\hline $\begin{array}{l}\text { R03 - препараты для лечения обструктивных заболе- } \\
\text { ваний ДС }\end{array}$ & 1 & 1,27 & 2 & 1,74 & 2 & 0,09 \\
\hline R05 - противокашлевые препараты & 2 & 2,53 & 2 & 1,74 & 3 & 0,13 \\
\hline R06 - антигистаминные средства системного действия & 8 & 10,13 & 10 & 8,70 & 75 & 3,23 \\
\hline V- прочие препараты & 2 & 2,53 & 3 & 2,61 & 205 & $\mathbf{8 , 8 2}$ \\
\hline V03 - другие лечебные средства & 2 & 2,53 & 3 & 2,61 & 205 & 8,82 \\
\hline Итого & 79 & 100,00 & 115 & 100,00 & 2324 & 100,00 \\
\hline
\end{tabular}

Очень важно при формировании планового перечня закупок учитывать результаты сопоставительного анализа структуры назначаемого ассортимента и интенсивность потребления по группам ЛП. Так, например, группа С - сердечнососудистая система представлена в фактической терапии $19,1 \%$ ассортимента из семи подгрупп АТC-классификации, а по интенсивности потребления на нее приходится только $2,5 \%$ (59 назначений). Наиболее часто назначалась подгруппа С09 - средства, действующие на ренинангиотензивную систему (24 назначения).

Аналогичная ситуация характерна для препаратов группы $\mathrm{R}$ - дыхательная система, представлена 15 ЛП (13\%), на которые приходится 81 назначение $(3,5 \%)$. Основная часть назначений приходится на R06 - антигистаминные средства системного действия, которые входят в рекомендательные схемы терапии псориаза (75 назначений). Незначительные доли препаратов в группах: M (3,2\%), R (3,5\%), L (4,3\%), J (0,8\%) свидетельствуют о том, что потребление ЛП этих групп не носит системного характера или связано с тяжестью заболевания, индивидуальными особенностями пациентов, наличием у них сопутствующих патологий.

Определение коэффициента интенсивности назначения (Ки) по каждому лекарственному препарату показало, что самые высокие показатели характерны для натрия тиосульфата (Ки $=0,96$, подгруппа V03 - другие лечебные средства), гемодеза (Ки $=0,94$, подгруппа В05 - кровезаменители и перфузионные растворы), аевита (Ки = 0,83, подгруппа A11 - витамины), пиридоксина (Ки $=0,80$, подгруппа A11 - витамины), цианокобаламина (Ки $=0,80$, подгруппа В03), фолиевой кислоты (Ки $=0,68$, подгруппа В03 - антианемические препараты), пирогенала (Ки $=0,51$, подгруппа L03 - иммуностимуляторы), липоевой кислоты (Ки $=0,48$, подгруппа A16 - другие препараты для лечения заболеваний ЖКТ и нарушений обмена веществ), вазелина (Ки $=0,48$, подгруппа D02). Применение большого количества препаратов из общего перечня фактической лекарственной терапии с высокой интенсивностью обусловлено комплексным подходом к лечению больных псориазом, необходимостью назначения препаратов из разных групп АТС-классификации. Это свидетельствует о сложности терапии, необходимости проведения современных лабораторно-диагностических исследований, трудозатратах персонала, так как лекарственные формы назначаются преимущественно в виде растворов для инъекций или местно.

На следующем этапе с использованием фармацевтического анализа был определен краткий перечень лекарственных средств основного спроca, включающий 53 наименования ЛП. Для подтверждения правильности критериев отбора при формировании краткого перечня был использован $\mathrm{ABC}$-анализ, позволивший установить, что более $80 \%$ всех назначений в условиях стационара составляли 22 ЛП, что соответствуют 19,1\% общего ассортимента фактических назначений (группа А). Важной характеристикой потребления ЛП является наличие на первых позициях $\mathrm{ABC}$ анализа ЛП специфического действия, используемых при псориазе. Еще 15\% потребления формировал 31 ЛП - 26\% фактических назначений (группа В). Остальные 62 ЛП (53,9\%) общего перечня суммарно потреблялись в объеме порядка 5\% (группа С). Установлено, что именно группы 
А и В полностью вошли в краткий перечень и на них должно быть направлено внимание медицинской организации при анализе и формировании перечня закупок.

Согласно методологии фармацевтического анализа для каждого ЛП краткого перечня лекарственных средств основного спроса были определены следующие статистические показатели: средний расход препарата на одного пациента, мода, медиана, коэффициент интенсивности потребления, коэффициент вариации $[6,7]$. Для 16 ЛП коэффициент вариации превышал $30 \%$, но с учетом высокого коэффициента интенсивности потребления и рекомендаций по использованию существующих схем лекарственной терапии, прогнозные значения были рассчитаны и для этих препаратов. Полученные данные позволили сформировать прогноз потребности в финансовых средствах по всем 53 наименованиям ЛП, представленных в перечне лекарственных средств основного спроса исходя из прогнозного значения количества больных (170 человек). В соответствии с проведенными расчетами медицинской организации необходимо запланировать 287,77 тыс. руб. для закупки ЛП для оказания медицинской и фармацевтической помощи больным псориазом. В зависимости от ситуации с объемом выделяемых финансовых потоков, структурой тарифа медицинская организация может регулировать как структуру ассортимента, так и стоимость лекарственного портфеля.

В связи с тем, что формирование заявки для закупок осуществляется по МНН, нами был предложен методический подход, позволяющий медицинской организации не нарушая законодательство, сформировать как оптимальный перечень ЛП, так и предварительно запланировать необходимые средства для пациентов с псориазом. Применение интегрированного $\mathrm{ABC} / \mathrm{XYZ}$ анализа потребления позволяет определить приоритетные группы препаратов для закупок с учетом всех требований формирования перечней (таблица 2).

Далее все ЛС в соответствии с полученным статусом в зависимости от группы интегрированного ABC/XYZ-анализа были квалифицированы в условные статусные группы (таблица 3). К I группе были отнесены ЛС со статусом вхождения в группы AX, BX, и/или имеющие высокие показатели интенсивности потребления (AZ, BZ, CZ). Это объясняется тем, что годовая потребность (месячная, квартальная) со статистической достоверностью может быть предусмотрена для ЛП групп $\mathrm{AX}$ и $\mathrm{BX}$, а для $\mathrm{AZ}, \mathrm{BZ}, \mathrm{CZ}$, несмотря на нестабильность или стохастичность потребления, вследствие высоких Ки позволяет прогнозировать необходимые объемы ЛП. Группу II сформирова- ли те МНH, которые встречались в группах АХ, BX. CX и имели невысокие значения Ки. III группа - это МНH, которые входили в группы A и C (АВC-анализ), и имели низкие значения Ки. IV группа представлена ЛС, имеющими низкое значение Ки, преимущественно назначались для лечения сопутствующих патологий.

Детальный анализ показал, что I группа преимущественно представлена МНH группы АХ (3 МНH: бетаметазон, бетаметазон + салициловая кислота, декспантенол) и AZ (3 MHН: ретинол + витамин Е (ТН - аевит), калия хлорид, комбинация (ТН - гемодез), натрия тиосульфат). Наличие МНH: пиридоксина из группы BZ и цианокобаламина $\mathrm{CZ}$ вызвано высокими значениями Ки и необходимостью включения в схемы лекарственной терапии данных ЛС.

Группа II, представленная восемью наименованиями ЛС, характеризуется наличием групп интегрированного ABC/XYZ-анализа: AX (MHН: флуметазон + салициловая кислота), ВХ (МНH: вазелиновое масло и гидрокортизон, который одновременно в зависимости от формы выпуска входит в две группы BX и CX, в которую также входит МНН флуоцинолона ацетонид). Кроме того, данный перечень формируют группы AY (МНH - фолиевая кислота) и AZ (ТН - пирогенал и фосфолипиды в инъекционной форме).

Наименее численная по составу это III группа, которая представлена различными подгруппами по АТC-классификации и по классификации $\mathrm{ABC} / \mathrm{XYZ}$-анализа. Все эти ЛС имеют важное значение в комплексной терапии псориаза.

Группа IV включает $23 \mathrm{MHH}$ в основном группы CX 26,1\% (МНH: бисопролол, клотримазол, клобетазон, метилпреднизолона ацепонат, гидрокортизон + окситетрациклин). Все МНH, кроме бисопролола $(\mathrm{C} 07 \mathrm{AB})$ и клотримазола (D01AC) относятся к подгруппе D07A - кортикостероиды с низкой активностью, которая широко используется в лечении псориаза. Отнесение данных MHН к IV группе связано с очень низкими показателями Ки и наличием представителей данной подгруппы в перечне ЛС I группы. Наличие трех МНН подгруппы M01А - нестероидные противовоспалительные и противоревматические средства (диклокфенак, мелоксикам, нимесулид) объясняется как разными по видам формами, а также побочными действиями ЛС данной подгруппы. Такую же долю занимает группа BZ $(26,1 \%)$, но превалирующая доля принадлежит группе CZ (30,4\%), которая представлена семью МНH из разных подгрупп АТС-классификации, что свидетельствует о наличии разноплановых сопутствующих заболеваний у пациентов с псориазом. 
Результаты интегрированного ABC/XYZ-анализа потребления лекарственных средств больными псориазом по международным непатентованным наименованиям

\begin{tabular}{|c|c|c|c|c|c|c|c|c|}
\hline $\begin{array}{l}\text { Код } \\
\text { АТС }\end{array}$ & AX (MHH) & Ки & $\begin{array}{l}\text { Код } \\
\text { АТС }\end{array}$ & BX (MHH) & Ки & $\begin{array}{r}\text { Код } \\
\text { АТС }\end{array}$ & CX (MHН) & Ки \\
\hline D07AC & Бетаметазон (мазь) & 0,755 & D02AC & Вазелиновое масло (мазь) & 0,476 & D07AC & Флуоцинолона ацетонид (линим.) & 0,435 \\
\hline \multirow[t]{2}{*}{ D07XC } & \multirow{2}{*}{$\begin{array}{l}\text { Бетаметазон + Салициловая } \\
\text { кислота (мазь/лосьон) }\end{array}$} & \multirow[t]{2}{*}{0,419} & \multirow[t]{2}{*}{ D07BA } & \multirow{2}{*}{$\begin{array}{l}\text { Гидрокортизов в комб. } \\
\text { с антисептиками (мазь) }\end{array}$} & \multirow[t]{2}{*}{0,262} & D07AA & Гидрокортизон (мазь) & 0,141 \\
\hline & & & & & & M02AA & Индометацин (мазь) & 0,141 \\
\hline D03AX & Декспантенол (мазь) & 0,398 & D07AA & Гидрокортизон (крем) & 0,079 & \multirow[t]{2}{*}{ D07CA } & Гидрокортизон + & \multirow[t]{2}{*}{0,063} \\
\hline D07AB & Алклометазон (крем) & 0,120 & D07AC & Мометазон (мазь) & 0,052 & & Окситетрациклин (мазь) & \\
\hline \multirow[t]{2}{*}{ D07XB } & \multirow{2}{*}{$\begin{array}{l}\text { Флуметазон + Салициловая } \\
\text { кислота (мазь) }\end{array}$} & \multirow[t]{2}{*}{0,120} & & & & D01AC & Клотримазол (мазь) & 0,031 \\
\hline & & & & & & D07AC & $\begin{array}{l}\text { Метилпреднизолона ацепонат } \\
\text { (мазь) }\end{array}$ & 0,031 \\
\hline \multirow{2}{*}{\multicolumn{6}{|c|}{ 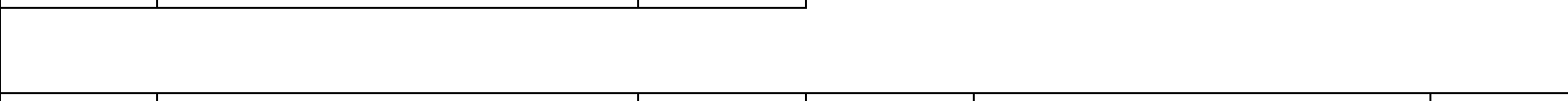 }} & $\mathrm{C} 07 \mathrm{AB}$ & Бисопролол табл. & 0,026 \\
\hline & & & & & & D07AB & Клобетазон (мазь) & 0,021 \\
\hline $\begin{array}{l}\text { Код } \\
\text { АТС }\end{array}$ & AY (MHH) & Ки & Код АТС & BY (MHH) & Ки & $\begin{array}{c}\text { Код } \\
\text { АТС }\end{array}$ & CY (МHН) & Ки \\
\hline B03BB & Фолиевая кислота (табл.) & 0,675 & A16AX & Тиоктовая кислота (табл.) & 0,476 & R06AX & Лоратадин (табл.) & 0,162 \\
\hline \multirow[t]{4}{*}{ R06AC } & \multirow{4}{*}{\multicolumn{2}{|c|}{ Хлорпирамин (р-р для ин.) }} & \multirow{5}{*}{ Код АТС } & \multirow[t]{4}{*}{ Цефтриаксон (пор. д/ин.) } & \multirow[t]{4}{*}{0,026} & M01AC & Мелоксикам (табл.) & 0,047 \\
\hline & & & & & & R06AX & Дезлоратадин (табл.) & 0,026 \\
\hline & & & & & & M01AB & Индометацин (табл) & 0,021 \\
\hline & & & & & & R06AE & Цетиризин (табл.) & 0,021 \\
\hline \multirow{2}{*}{$\begin{array}{c}\text { Код } \\
\text { АТC } \\
\text { V03AB }\end{array}$} & AZ (MHH) & Ки & & BZ (MHH) & Ки & $\begin{array}{l}\text { Код } \\
\text { АТС }\end{array}$ & CZ (MHH) & Ки \\
\hline & $\begin{array}{l}\text { Натрия тиосульфат } \\
\text { (р-р для ин.) }\end{array}$ & 0,963 & A11HA & Пиридоксин (р-р д/ин.) & 0,801 & $\begin{array}{l}\text { B03BA0 } \\
1\end{array}$ & Цианокобаламин (р-р для ин.) & 0,801 \\
\hline B05AA & $\begin{array}{l}\text { Гемодез р-р для инф., } \\
\text { фл. } 400 \text { мл }\end{array}$ & 0,937 & $\mathrm{~A} 05 \mathrm{C}$ & Фосфолипиды (капс.) & 0,126 & N06BX & Глицин (табл.) & 0,262 \\
\hline A11JA & Ретинол + Витамин Е (капс.) & 0,827 & M01AX & Нимесулид (табл.) & 0,094 & \multirow{2}{*}{$\mathrm{B} 01 \mathrm{AC}$} & \multirow{2}{*}{$\begin{array}{l}\text { Ацетилсалициловая кислота + } \\
\text { Магния гидроксид (табл.) }\end{array}$} & \multirow[t]{2}{*}{0,052} \\
\hline L03AX & Пирогенал - ТН & 0,513 & C09AA & Эналаприл (табл.) & 0,089 & & & \\
\hline $\mathrm{A} 05 \mathrm{C}$ & Фосфолипиды (р-р для ин.) & 0,246 & \multirow{2}{*}{ N05BX } & \multirow{2}{*}{$\begin{array}{l}\text { Тетраметилтетраазабицик- } \\
\text { лооктандион (Адаптол) } \\
\text { (табл.) }\end{array}$} & 0,084 & V03AB & Натрия тиосульфат (пор.) & 0,052 \\
\hline A05BA & Силимарин (Карсил) (драже) & 0,225 & & & & M01AB & Диклофенак (р-р для ин.) & 0,047 \\
\hline V03AB & Димеркаптопропансульфонат & 0,058 & R06AC & Хлоропирамин табл. & 0,073 & $\mathrm{~A} 02 \mathrm{BC}$ & Омепразол (капс.) & 0,042 \\
\hline & натрия (р-р для ин.) & & A12AA & $\begin{array}{l}\text { Кальция глюконат } \\
\text { (р-р д/ин.) }\end{array}$ & 0,068 & C03DA & Спиронолактон (капс.) & 0,037 \\
\hline R06AC & Хлоропирамин (р-р для ин.) & 0,042 & J05AX & Умифеновир (капс.) & 0,026 & N07CA & Циннаризин (табл.) & 0,031 \\
\hline & & & & & & R06AA & Дифенгидрамин (р-р для ин.) & 0,026 \\
\hline
\end{tabular}


Распределение препаратов на группы в зависимости от их статуса

по результатам интегрированного ABC/XYZ-анализа

\begin{tabular}{|c|c|c|c|c|c|c|c|}
\hline \multicolumn{8}{|c|}{$\begin{array}{l}\text { Группы лекарственных препаратов } \\
\text { в зависимости от их статуса по МНН }\end{array}$} \\
\hline \multicolumn{2}{|r|}{ I группа } & \multicolumn{4}{|c|}{ II группа } & \multicolumn{2}{|r|}{ III группа } \\
\hline $\begin{array}{l}\text { Код } \\
\text { АТС } \\
\end{array}$ & Наименование ЛС & $\begin{array}{l}\text { Код } \\
\text { АТС } \\
\end{array}$ & \multicolumn{3}{|c|}{ Наименование ЛС } & $\begin{array}{c}\text { Код } \\
\text { АТС }\end{array}$ & Наименование ЛС \\
\hline A11HA & $\begin{array}{l}\text { Пиридоксин (р-р д/ин.) } \\
\text { - ВZ (ЖНВЛП) }\end{array}$ & $\mathrm{A} 05 \mathrm{C}$ & \multicolumn{3}{|c|}{$\begin{array}{l}{ }^{\prime} \text { Фосфолипиды (р-р для } \\
\text { ин.) - AZ }\end{array}$} & A05BA & $\begin{array}{l}{ }^{\mathrm{T}} \text { Силимарин (смесь } \\
\text { флаваноидов) - AZ }\end{array}$ \\
\hline A11JA & $\begin{array}{l}{ }^{1} \text { Ретинол + Витамин Е } \\
\text { (капс.) - AZ }\end{array}$ & A16AX & \multicolumn{3}{|c|}{$\begin{array}{l}\text { Тиоктовая кислота } \\
\text { (табл.) - ВY } \\
\text { (ЖНВЛП) }\end{array}$} & N06BX & Глицин (табл.) - CZ \\
\hline B03BA & $\begin{array}{l}\text { Цианокобаламин (p-p } \\
\text { для ин.) - CZ } \\
\text { (ЖНВЛП) }\end{array}$ & B03BB & \multicolumn{3}{|c|}{$\begin{array}{l}\text { Фолиевая кислота } \\
\text { (табл.) - АY } \\
\text { (ЖНВЛП) }\end{array}$} & R06AX & $\begin{array}{l}\text { Лоратадин (табл.) - CY } \\
\text { (ЖНВЛП) }\end{array}$ \\
\hline B05AA & $\begin{array}{l}{ }^{1} \text { Калия хлорид, комби- } \\
\text { нация (ТН - Гемодез р-p } \\
\text { для ин.) - AZ }\end{array}$ & D02AC & \multicolumn{3}{|c|}{$\begin{array}{l}\text { Парафин жидкий (ва- } \\
\text { зелиновое масло) (мазь) } \\
\text { - ВX }\end{array}$} & D07AB & $\begin{array}{l}\text { Алклометазон (крем) - } \\
\text { АХ }\end{array}$ \\
\hline D03AX & $\begin{array}{l}\text { Декспантенол (мазь) - } \\
\text { AX }\end{array}$ & D07AA & \multicolumn{3}{|c|}{$\begin{array}{l}\text { Гидрокортизон } \\
\text { (крем/мазь) - ВX/CX }\end{array}$} & M02AA & $\begin{array}{l}\text { Индометацин (мазь) - } \\
\text { СX }\end{array}$ \\
\hline D07AC & $\begin{array}{l}\text { Бетаметазон (мазь) - } \\
\text { AX }\end{array}$ & D07AC & \multicolumn{3}{|c|}{$\begin{array}{l}\text { Флуоцинолона ацето- } \\
\text { нид (линим.) - СX }\end{array}$} & Итого & 5 \\
\hline D07BA & $\begin{array}{l}\text { Гидрокортизов в комб. } \\
\text { с антисепт. (мазь) - ВX }\end{array}$ & D07XB & \multicolumn{3}{|c|}{$\begin{array}{l}\text { Флуметазон } \\
+ \text { Салициловая кислота } \\
\text { (мазь) - AX }\end{array}$} & & \\
\hline \multirow[t]{2}{*}{ D07XC } & \multirow{2}{*}{$\begin{array}{l}\text { Бетаметазон + Салици- } \\
\text { ловая кислота } \\
\text { (мазь/лосьон) - AX }\end{array}$} & L03AX & \multicolumn{3}{|c|}{$\begin{array}{l}{ }^{3} \text { Пирогенал }{ }^{\mathrm{TH}} \text { (р-р для } \\
\text { ин.) }-\mathrm{AZ}\end{array}$} & & \\
\hline & & \multirow[t]{3}{*}{ Итого } & \multirow{3}{*}{\multicolumn{3}{|c|}{8}} & & \\
\hline V03AB & $\begin{array}{l}\text { Натрия тиосульфат (p-p } \\
\text { для ин.) - AZ } \\
\text { (ЖНВЛП) }\end{array}$ & & & & & & \\
\hline Итого & 9 & & & & & & \\
\hline \multicolumn{8}{|c|}{ IV группа } \\
\hline $\begin{array}{l}\text { Код } \\
\text { АТС } \\
\end{array}$ & \multicolumn{3}{|c|}{$\begin{array}{c}\text { Наименование } \\
\text { ЛС } \\
\end{array}$} & Код АТС & \multicolumn{3}{|c|}{$\begin{array}{c}\text { Наименование } \\
\text { ЛС } \\
\end{array}$} \\
\hline $\mathrm{A} 02 \mathrm{BC}$ & \multicolumn{3}{|c|}{ Омепразол (капс.) - CZ (ЖНВЛП) } & J01DD & \multicolumn{3}{|c|}{ Цефтриаксон (пор. д/ин.) - ВY (ЖНВЛП) } \\
\hline $\mathrm{A} 05 \mathrm{C}$ & \multicolumn{3}{|c|}{ ' Фосфолипиды (капс.) - BZ } & J05AX & \multicolumn{3}{|c|}{ Умифеновир (капс.) - ВZ (ЖНВЛП) } \\
\hline A12AA & \multicolumn{3}{|c|}{$\begin{array}{l}\text { Кальция глюконат (р-р д/ин.) - BZ } \\
\text { (ЖНВЛП) }\end{array}$} & $\mathrm{M} 01 \mathrm{AB}$ & \multicolumn{3}{|c|}{$\begin{array}{l}\text { Диклофенак (р-р для ин.) - CZ } \\
\text { (ЖНВЛП) }\end{array}$} \\
\hline B01AC & \multicolumn{3}{|c|}{$\begin{array}{l}{ }^{\circ} \text { Ацетилсалициловая кислота, комбинации } \\
\text { (табл.) - CZ }\end{array}$} & M01AC & \multicolumn{3}{|c|}{ Мелоксикам (табл.) - CY } \\
\hline C03DA & \multicolumn{3}{|c|}{ Спиронолактон (капс.) - CZ (ЖНВЛП) } & M01AX & \multicolumn{3}{|c|}{ Нимесулид (табл.) - BZ } \\
\hline $\mathrm{C} 07 \mathrm{AB}$ & \multicolumn{3}{|c|}{$\begin{array}{l}\text { Бисопролол (табл.) - СX } \\
\text { (ЖНВЛП) }\end{array}$} & N05BX & $\begin{array}{l}{ }^{\mathrm{T}} \mathrm{TeT} \\
(\mathrm{TH}\end{array}$ & $\begin{array}{l}\text { Аметилтет1 } \\
\text { Адаптол) }\end{array}$ & $\begin{array}{l}\text { азаби-циклооктандион } \\
\text { габл.) - BZ }\end{array}$ \\
\hline C09AA & Эналаприл (табл.) - BZ () & КНВЛП) & & N07CA & Цин & аризин (та & I.) $-\mathrm{CZ}$ \\
\hline $\mathrm{D} 01 \mathrm{AC}$ & Клотримазол (мазь) - CX & & & R06AA & $\begin{array}{l}\text { Диф } \\
\text { (ЖН }\end{array}$ & $\begin{array}{l}\text { нгидрамин } \\
\text { ЛП) }\end{array}$ & (р-р для ин.) - CZ \\
\hline D07AB & Клобетазон (мазь) - СX & & & R06AC & $\begin{array}{l}\text { Хлоा } \\
\text { (ЖН }\end{array}$ & $\begin{array}{l}\text { Іирамин (1 } \\
\text { ЛП) }\end{array}$ & р для ин./табл.) - AZ/BZ \\
\hline D07AC & Мометазон (мазь) - ВX () & КНВЛП) & & V03AB & Натр & гя тиосуль & ат (пор.) - CZ \\
\hline D07AC & Метилпреднизолона ацег & онат (мазь) & $-\mathrm{CX}$ & V03AB & ${ }^{\mathrm{I}}$ Дим & ркаптопрс & гансульфонат натрия (ТН \\
\hline D07CA & $\begin{array}{l}\text { Гидрокортизон + } \\
\text { Окситетрациклин (мазь) }\end{array}$ & & & & & тиол) (p-p & ля ин.) - AZ (ЖНВЛП) \\
\hline Итого & 23 & & & & & & \\
\hline
\end{tabular}

Примечание: ${ }^{1}$ - Национальное непатентованное наименование. ${ }^{2}-$ Фармакопейное наименование. ${ }^{3}-$ Пирогенал - препарат имеет только ТН. 


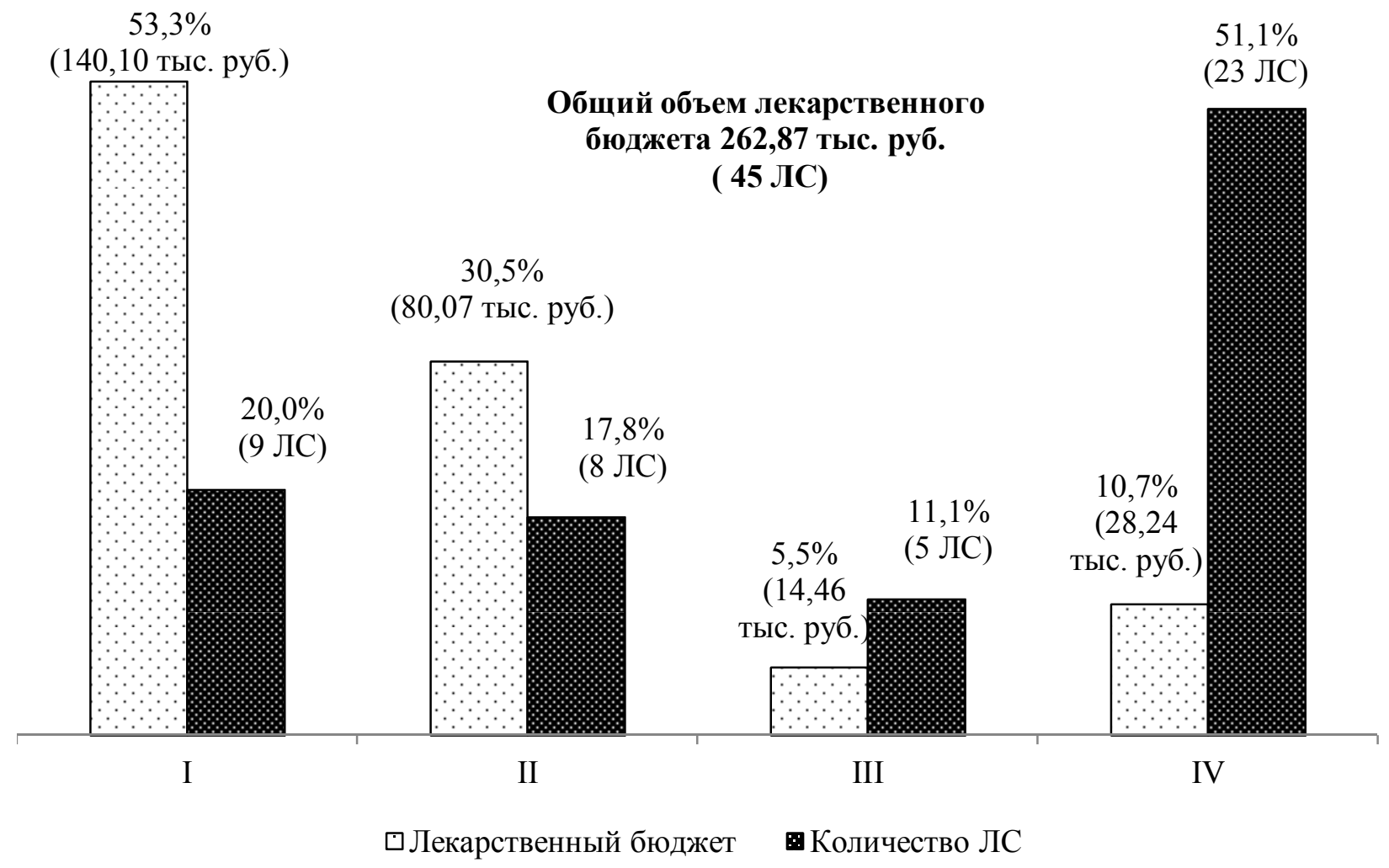

Рис. 2. Общая характеристика статусных групп препаратов.

По нашему мнению, для оказания качественной и своевременной терапии, позволяющей в ограниченные сроки улучшить качество жизни больных с псориазом и добиться стойкой ремиссии, медицинской организации необходимо формировать заявку на основании перечня ЛС, включающего номенклатурные позиции групп I, II, III перечней. Исходя из статистических показателей (средний расход, Ки) и рассчитанного прогнозного значения количества больных псориазом на 2017 год, была спрогнозирована потребность в финансовых средствах на закупку ЛС по каждой группе и определен для лечения больных псориазом лекарственный бюджет специализированной медицинской организации (рисунок 2).

Выявлено, что наиболее затратной является I группа, которая по количеству занимает только $20 \%$ ассортимента, но для ее закупки необходимо более половины финансовых средств $(53,3 \%)$ и она включает самые необходимые ЛС для оказания фармацевтической помощи больным с псориазом. Наименее затратной среди всех групп как по количеству, так и по объему финансовых средств $(14,46$ тыс. руб.) является III группа, но закупка ЛП данной группы должна осуществляться в полном объеме исходя из структуры ассортимента.

В перечне присутствуют 18 ЛП из списка ЖНВЛП, из которых $66,7 \%$ входят в IV группу и только шесть наименований в другие группы. Например, подгруппа D07 - глюкокортикоиды, применяемые в дерматологии, в перечне ЖНВЛП представлена только одним МНH мометазон, который в нашем случае входит в IV группу, исходя из низкого значения Ки. Другие ЛП из перечня ЖНВЛП, представленные в IV группе (например, спиронлактон, бисопролол, диклофенак, хлорпирамин и другие), используются для лечения сопутствующих заболеваний больных псориазом, наличие которых подтверждают и данные литературных источников $[1,4]$. Лекарственный бюджет при наличии достаточного количества финансовых средств составляет для всех четырех групп 262,87 тыс. руб., что на 24,9 тыс. руб. меньше по сравнению с расчетами, проведенными на основании фармацевтического анализа.

Таким образом, результаты организационноэкономических исследований позволили определить многие важные показатели для формирования перечня закупок на основании статистически значимых данных, запланировать лекарственный бюджет для оказания качественной и своевременной медицинской и фармацевтической помощи. Исходя из экономической ситуации финансирования специализированной медицинской организации, настоящее исследование позволяет планово-экономическим службам и/или специалистам, участвующим в формировании перечня закупок, использовать различные полученные данные в зависимости от условий их работы. Следует обратить внимание на использование оптимальных схем лечения, возможность быстрой замены лекарственных препаратов, что достигается наличием значительного ассортиментного портфеля 
медицинской организации. Все это позволят эффективно и быстро достичь улучшения качества жизни, добиться стойкой ремиссии заболевания и тем самым снизить прямые платежи больных псориазом на медицинские услуги.

\section{ЛИТЕРАТУРА}

1. Бакулев А.Л., Шагова Ю.В., Козлова И.В. Псориаз как системная патология // Саратовский научномедицинский журнал. - 2008. - Т. 4, № 1. C. 13-20.

2. Болевич С.Б., Уразалина А.А. Псориаз: современный взгляд на этиопатогенез // Вестник Российской военно-медицинской академии. - 2013. № 2 (42). - С. 202-206.

3. Владимирова И.С., Монахов К.Н. Влияние различных факторов на течение псориаза и качество жизни больных // Доктор.ру. - 2012. - № 4. C. 47-51.

4. Кунгуров Н.В., Филимонкова Н.Н., Голобияов В.И., Корхмазова С.A. Генетические факторы этиологии и патогенеза псориаза // Вестник дерматологии и венерологии. - 2011. - № 1. - С. 23-27.

5. Минеева А.А., Кожушная О.С., Знаменская Л.Ф., Чикин В.В., Фриго Н.В. Результаты изучения генетических факторов предрасположенности к псориазу среди населения Российской Федерации // Вестник дерматологии и венерологии. - 2013. № 5. - С. 78-90.
6. Овод А.И., Дремова Н.Б., Солянина В.А. Методические подходы формирования лекарственного бюджета для специализированых отделений стационаров // Сибирский медицинский журнал. 2005. - № 6. - С. 74-80.

7. Овод А.И., Солянина В.А., Хорляков К.В. Затраты на лекарственную и медицинскую помощь при искусственном прерывании беременности. Сколько стоит аборт? // Ремедиум. - 2016. - № 10. C. 67-74.

8. Толмачева Н.В., Анисимова А.Н. Современный взгляд на этиологию и патогенез псориаза // Фундаментальные исследования. - 2016. - № 1-10. С. 2118-2121.

9. Федеральные клинические рекомендации по ведению больных псориазом [Электронный ресурс] M., 2013. - 2 Режим доступа: http://mzdrav.rk.gov.ru/file/Psoriaz 05052014 Klinic heskie rekomendacii.pdf, свободный (19.05.2017)

10. Федеральные клинические рекомендации. Дерматовенерология. 2015: Болезни кожи. Инфекции, передаваемые половым путем - 5-е изд., перераб. и доп. - М. : Деловой экспресс, 2016. - 768 с.

11. Центральный НИИ организации и информатизации здравоохранения. Раздел «Статистика». Дерматовенерологическая служба. [Электронный ресурс]. - Режим доступа: http://mednet.ru/statistika/dermatovenerologicheskaya -sluzhba.html?lang=ru, свободный (19.05.2017) 